\title{
Enhancement of Anaerobic Digestion of Waste-Activated Sludge by Conductive Materials under High Volatile Fatty Acids-to-Alkalinity Ratios
}

\author{
Paolo S. Calabrò ${ }^{1, * \mathbb{D}}$, Filippo Fazzino ${ }^{1}$, Carlo Limonti ${ }^{2} \mathbb{D}$ and Alessio Siciliano ${ }^{2, * \mathbb{D}}$ \\ 1 Department of Civil, Energy, Environmental and Materials Engineering, \\ Mediterranean University of Reggio Calabria, Via Graziella, loc. Feo di Vito, I-89122 Reggio Calabria, Italy; \\ filippo.fazzino@unirc.it \\ 2 Department of Environmental Engineering, University of Calabria, via P. Bucci, 87036 Rende (CS), Italy; \\ carlo.limonti@unical.it \\ * Correspondence: paolo.calabro@unirc.it (P.S.C.); alessio.siciliano@unical.it (A.S.)
}

check for updates

Citation: Calabrò, P.S.; Fazzino, F.; Limonti, C.; Siciliano, A.

Enhancement of Anaerobic Digestion of Waste-Activated Sludge by Conductive Materials under High Volatile Fatty Acids-to-Alkalinity Ratios. Water 2021, 13, 391. https://doi.org/10.3390/w13040391

Academic Editors: Constantinos V. Chrysikopoulos and Maria

Cristina Collivignarelli

Received: 4 January 2021

Accepted: 28 January 2021

Published: 3 February 202

Publisher's Note: MDPI stays neutral with regard to jurisdictional claims in published maps and institutional affiliations.

Copyright: (c) 2021 by the authors. Licensee MDPI, Basel, Switzerland. This article is an open access article distributed under the terms and conditions of the Creative Commons Attribution (CC BY) license (https:/ / creativecommons.org/licenses/by/ $4.0 /)$.

\begin{abstract}
Anaerobic digestion (AD) represents a suitable option for the management of the wasteactivated sludge (WAS) produced in municipal wastewater treatment plants. Nevertheless, due to its complex characteristics, WAS is often barely degradable under conventional anaerobic processes. The use of conductive materials during AD provides a promising route for enhancing WAS digestion, through the effects of direct inter-species electron transfer (DIET). The present paper aims to evaluate the effects of the addition of four different materials - granular activated carbon (GAC), granular iron, and aluminium and steel scrap powders-in semi-continuous lab-scale reactors under very high volatile fatty acids-to-alkalinity ratios. In particular, the use of metallic aluminium in WAS digestion was investigated for the first time and compared to the other materials. The AD of WAS without the addition of conductive materials was impossible, while the use of steel powder and zero-valent iron is shown not to improve the digestion process in a satisfactory way. On the contrary, both GAC and Al allow for effective WAS degradation. At stable conditions, methane yields of about $230 \mathrm{NmL}_{\mathrm{CH} 4} / \mathrm{g}_{\mathrm{VS}}$ and $212 \mathrm{NmL}_{\mathrm{CH} 4} / \mathrm{g}_{\mathrm{VS}}$ are recorded for GAC- and Al-amended reactors, respectively. These two materials are the most promising in sustaining WAS AD through DIET also in case of unbalanced volatile fatty acids-to-alkalinity ratios.
\end{abstract}

Keywords: aluminium; alkalinity; anaerobic digestion; granular activated carbon; waste-activated sludge; zero-valent iron

\section{Introduction}

The most common wastewater treatment process worldwide is activated sludge, introduced at the beginning of the 20th century in the United Kingdom by two engineers, Edward Ardern and W.T. Lockett [1]. The main by-product of the process is waste-activated sludge (WAS), which is separated from clarified wastewater in secondary clarifiers and is only partially recycled to sustain the process [2]; when wasted, it contains about $1 \%$ solids by weight typically [3]. Depending on the wastewater treatment plant (WWTP) layout, if a primary clarifier is present, primary sludge is also produced. Waste-activated (and, if present, primary) sludge must be subjected to treatment before utilization or disposal since it contains partially degraded organic matter, nutrients, pathogens and various toxic organic compounds, such as surfactants, hydrocarbons and residues derived from plastics $[3,4]$.

In this context, anaerobic digestion (AD) can play a primary role in sludge management, as it allows for the required biological stabilization for energy recovery through biogas production and for greenhouse gases reduction at the same time [5-11]. 
Unfortunately, the efficient conversion of WAS to biomethane in a full-scale plant is problematic [12-14]; in fact, the actual production often represents only a small fraction $(20-30 \%)$ of the theoretical one, typically on the order of $450-600 \mathrm{NmL}_{\mathrm{CH} 4} / \mathrm{g}_{\mathrm{VS}}[15,16]$.

Low yields have been mainly attributed to the low biodegradability of WAS constituents which are not directly available for assimilation by bacteria [17]. In particular, the difficulty in converting complex organic matter into simpler substrates which are then used by bacteria makes hydrolysis the limiting step of the whole process. In order to improve biodegradability, many pre-treatments have been proposed including thermal hydrolysis, mechanical (such as ultrasound, high pressure and lysis), advanced chemical oxidation (mainly $\mathrm{O}_{3}$ - and $\mathrm{H}_{2} \mathrm{O}_{2}$-based techniques), and alkali processes [18-21].

A different approach to increasing the conversion of organic sludge compounds into biomethane is based on the metabolic enhancement of microorganisms. Parameters such as the ratio between volatile fatty acids and alkalinity (VFA/ALK), $\mathrm{pH}$, temperature, and oxidation-reduction potential directly influence microbial and enzymatic activity, as well as the presence of macro- and micro-nutrients [22-24].

The ecology of the process is also of capital importance, as syntrophic interactions among the different strains involved are crucial; for example, the syntrophic association between hydrogenotrophic methanogens and acidogenic bacteria allows preservation of hydrogen partial pressure in the system below the level which ensures the thermodynamic feasibility of the process [17]. Similarly, acetoclastic methanogens consume acetate in order to produce carbon dioxide and methane; in doing so, they maintain the conditions for acetate production from volatile fatty acids (VFAs) performed by fermentative bacteria [25] As both interactions consist of oxidation and reduction reactions, they require electron exchanges among syntrophic microorganisms. In particular, inter-species electron transfer (IET) with hydrogen and formate as electron carriers is known to be a major pathway. However, recent studies [26-28] have shown that electrons can flow from one cell to another without being shuttled by molecules but, instead, directly through direct contact, making methane production faster and thermodynamically more efficient. This phenomenon has been called direct inter-species electron transfer (DIET) [29,30] and can occur through electrically conductive pili, electrically conductive materials, and electron transport proteins on cell surfaces [31].

Conductive materials are known to promote DIET in AD processes [25]; for instance, carbon-based materials, such as granular activated carbon (GAC), carbon cloth, and biochar, thanks to their high surface area and electrical conductivity, have been added to reactors to facilitate electrical connections in microorganisms attached to granules, thus providing them the possibility to grow [31,32]. Furthermore, these materials are commonly used in AD bioreactors, owing to their microporous structure that allows them to adsorb toxic compounds which potentially inhibit methane production [33]. In regards to WAS AD, literature [34-36] shows a wide range of dosages $(0.125-35 \mathrm{~g} / \mathrm{L})$ and increase of methane production (+17.4-+241\%).

Considering metal-based materials, iron and its compounds have been widely used as conductive materials in AD processes. The reason for this resides in its corrosion in anaerobic conditions: according to the equations listed below, zero-valent iron reacts with water (Equation (1)) to produce hydrogen, while its hydroxide is not stable in anaerobic environments and is liable to be transformed into magnetite, as in Equation (2) [37].

$$
\begin{gathered}
\mathrm{Fe}^{0}+2 \mathrm{H}_{2} \mathrm{O} \rightarrow \mathrm{Fe}^{2+}+2 \mathrm{OH}^{-}+\mathrm{H}_{2} \\
3 \mathrm{Fe}(\mathrm{OH})_{2} \rightarrow \mathrm{Fe}_{3} \mathrm{O}_{4}+\mathrm{H}_{2}+2 \mathrm{H}_{2} \mathrm{O}
\end{gathered}
$$

Hence, the addition of iron can indirectly reduce $\mathrm{CO}_{2}$ present in biogas, as methane is produced by hydrogenotrophic methanogens thanks to the hydrogen formed through its corrosion. Furthermore, during iron corrosion, the buffering capacity of the system is improved. Finally, magnetite produced by the transformation of iron (II) hydroxide (Equation (2)) plays an important role in the DIET mechanism. In fact, according to 
Lovley [31], magnetite particles allow direct electron transfer between microbial species (e.g., Geobacter to Methanosarcina). Recent research [38-42] reports the use of several iron-based materials (e.g., zero-valent iron (ZVI) in granular, powdered or nanoscale form, clean and rusted scrap iron, magnetite) for enhancing AD of WAS; most of the tests were carried out in batch mode. Dosages show great variability $\left(0-20 \mathrm{mg} / \mathrm{L} ; 0-1 \mathrm{~g}_{\mathrm{ZVI}} / \mathrm{g}_{\mathrm{VS}}\right)$, as do the results; methane production increase is indicated in the range $13-186 \%$, in general yield increase is higher for batch experiments.

Therefore, DIET is a promising route for enhancing the AD of WAS in the circular economy framework, which could increase the energy self-sufficiency of the plants and reduce the expenses related to sludge disposal.

The specific aim of this experiment is the assessment and comparison of the effects of the addition of four different conductive materials (GAC, granular ZVI, and aluminium and steel scrap powders) in WAS AD in semi-continuous lab-scale reactors under very high VFA/ALK conditions. In particular, to the knowledge of the authors, the effect of the addition of aluminium on WAS AD and the effect of conductive materials addition under high VFA/ALK conditions are evaluated for the first time in literature. Aluminium was chosen because of its high electrical conductivity and relatively low toxicity; in fact, it is not included in the metals regulated in the case of land application in Europe [43]. The comparison of a conductive and adsorbent material like GAC and of highly conductive metallic materials allows us to verify whether DIET is likely to occur.

\section{Materials and Methods}

\subsection{Substrate, Inoculum, and Additives for Semi-Continuous Test}

The substrate used in the experiment was WAS produced in the "Gallico" WWTP located in Reggio Calabria (Calabria Region, Italy). This is a secondary treatment plant with pre-denitrification built for 35,000 P.E., which is actually overloaded (with incoming hydraulic load corresponding to about 50,000 P.E., on average).

Fresh WAS was collected at the inlet of the aerobic digester of the plant, as withdrawn from the secondary clarifier (thickening section is not present) every 20 days, corresponding to three times during the entire experimental period. After collection, it was gravitythickened in $2 \mathrm{~L}$ graduated cylinders for $24 \mathrm{~h}$ at room temperature and then stored at $4{ }^{\circ} \mathrm{C}$ until further use.

The inoculum used for the start-up of the semi-continuous test was liquid digestate coming from a local full-scale AD plant, which was mainly fed with manure and various residues from the agro-industry. It was sieved to remove fibrous materials (e.g., straw) and then kept in anaerobic conditions in an oven at $35^{\circ} \mathrm{C}$ for about a week before the experiments, in order to reduce as much as possible of the non-specific biogas production.

Substrate and inoculum were characterized according to standard methods [44], carrying out tests in triplicates.

Inoculum had $7.2 \%$ TS, VS were $76.2 \% \mathrm{TS}$, and $\mathrm{pH}$ was equal to 7.7 , while the characteristics of the substrate are summarized in Table 1.

Four different conductive materials were added in the $\mathrm{AD}$ process to promote the DIET mechanism: GAC (CARBOSORB 2040, $20 \times 40$ mesh; Comelt srl, Milan, Italy), ZVI (FERBLAST RI 850/3.5, mean grain size of $0.5 \mathrm{~mm}$ and coefficient of uniformity equal to 2 ; conductivity $1 \cdot 10^{7} \mathrm{~S} \cdot \mathrm{m}^{-1}$; Pometon srl, Venice, Italy), and aluminum (conductivity $3.5 \cdot 10^{7} \mathrm{~S} \cdot \mathrm{m}^{-1}$ ) and steel (conductivity $1.4 \cdot 10^{7} \mathrm{~S} \cdot \mathrm{m}^{-1}$ ) scrap powders, which were by-products collected from a local window fixture building workshop. For this reason, these two latter were pre-treated before use by sieving and then immersing in $\mathrm{NaOH}$ (Sigma-Aldrich) $0.1 \mathrm{M}$ alkaline solution at room temperature for $18 \mathrm{~h}$, in order to clean them from dirt, grease, or oil. At the end of the treatment, materials were washed several times with distilled water and then fed to the reactors. Each additive was added only at the beginning of the experiment, in the respective reactor, at a dosage of $10 \mathrm{~g} / \mathrm{L}$. This dosage was chosen following relevant literature [37,42]. 
Table 1. Substrate characterization.

\begin{tabular}{|c|c|c|c|}
\hline & Thickened WAS-I * & $\underset{* *}{\text { Thickened WAS-II }}$ & $\underset{* * *}{\text { Thickened WAS-III }}$ \\
\hline TS (\%) & $1.38 \pm 0.16$ & $1.39 \pm 0.14$ & $1.39 \pm 0.24$ \\
\hline VS (\%) & $1.11 \pm 0.26$ & $1.08 \pm 0.12$ & $1.10 \pm 0.31$ \\
\hline $\mathrm{pH}$ & 6.60 & 6.50 & 6.70 \\
\hline $\begin{array}{l}\text { Conductivity } \\
(\mathrm{mS} / \mathrm{cm})\end{array}$ & 7.30 & 1.50 & 1.43 \\
\hline $\operatorname{COD}(\mathrm{g} / \mathrm{L})$ & $15.29 \pm 0.19$ & $15.80 \pm 0.64$ & $14.91 \pm 0.49$ \\
\hline VFA $\left(\mathrm{g}_{\mathrm{CH}} \mathrm{COOH} / \mathrm{L}\right)$ & $1.27 \pm 0.03$ & $1.23 \pm 0.05$ & $1.20 \pm 0.02$ \\
\hline $\operatorname{ALK}\left(\mathrm{g}_{\mathrm{CaCO} 3} / \mathrm{L}\right)$ & $0.19 \pm 0.00$ & $0.11 \pm 0.00$ & $0.11 \pm 0.00$ \\
\hline $\mathrm{TN}(\mathrm{g} / \mathrm{L})$ & $0.46 \pm 0.02$ & $0.47 \pm 0.02$ & $0.46 \pm 0.01$ \\
\hline $\mathrm{N}-\mathrm{NH}_{4}{ }^{+}(\mathrm{g} / \mathrm{L})$ & $0.16 \pm 0.01$ & $0.10 \pm 0.01$ & $0.09 \pm 0.00$ \\
\hline $\mathrm{P}^{-\mathrm{PO}_{4}}{ }^{3-}(\mathrm{g} / \mathrm{L})$ & $0.10 \pm 0.00$ & $0.09 \pm 0.00$ & $0.08 \pm 0.00$ \\
\hline $\mathrm{SO}_{4}{ }^{2-}(\mathrm{g} / \mathrm{L})$ & $0.12 \pm 0.01$ & $0.15 \pm 0.01$ & $0.15 \pm 0.01$ \\
\hline $\mathrm{Fe}(\mathrm{mg} / \mathrm{L})$ & $49.88 \pm 3.75$ & $39.81 \pm 4.94$ & $37.24 \pm 3.78$ \\
\hline $\mathrm{Al}(\mathrm{mg} / \mathrm{L})$ & $173.34 \pm 4.43$ & $145.84 \pm 13.91$ & $143.57 \pm 2.85$ \\
\hline $\operatorname{Mn}(\mathrm{mg} / \mathrm{L})$ & $0.82 \pm 0.15$ & $0.68 \pm 0.19$ & $0.61 \pm 0.18$ \\
\hline $\mathrm{Zn}(\mathrm{mg} / \mathrm{L})$ & $9.06 \pm 0.11$ & $8.71 \pm 0.24$ & $7.60 \pm 0.2$ \\
\hline $\mathrm{Pb}(\mathrm{mg} / \mathrm{L})$ & N.D. & N.D. & N.D. \\
\hline $\mathrm{Cu}(\mathrm{mg} / \mathrm{L})$ & $3.03 \pm 0.39$ & $2.64 \pm 0.2$ & $2.47 \pm 0.26$ \\
\hline $\mathrm{Cr}(\mathrm{mg} / \mathrm{L})$ & N.D. & N.D. & N.D. \\
\hline $\mathrm{Ni}(\mathrm{mg} / \mathrm{L})$ & N.D. & N.D. & N.D. \\
\hline
\end{tabular}

\subsection{Batch Test Setup}

In order to assess the maximum biomethane production in the hydraulic retention time (HRT) set for the semi-continuous test (14 days), the three thickened WAS samples used as substrate were subjected to three different cycles of biochemical methane potential (BMP) tests (labelled as I, II, and III) under mesophilic conditions $\left(35 \pm 0.5{ }^{\circ} \mathrm{C}\right)$. Each cycle was performed in triplicate, using a method extensively adopted in previous experiments $[45,46]$.

Each bottle (WTW-Germany with 1.1 L volume) had three necks, two sealed with perforable septa allowing periodic biogas collection, while the main central neck was used to load the reactors at the beginning of the experiment and then was sealed with a stopper (Figure 1). The reactors were placed in a thermostatic cabinet at $35 \pm 0.5^{\circ} \mathrm{C}$ and mixed by a magnetic stirrer throughout the test period [33]. The generated biogas was measured three times per week. In particular, using a graduated syringe, $100 \mathrm{~mL}$ of biogas were taken from each bottle and transferred into an alkaline trap containing $750 \mathrm{~mL}$ of a $3 \mathrm{M} \mathrm{NaOH}$ solution. The amount of $\mathrm{NaOH}$ was very high to neutralize even large $\mathrm{CO}_{2}$ quantities (up to 1.125 moles). In this way, the carbon dioxide present in the biogas was rapidly and totally absorbed into the alkaline solution while the methane caused a pressure increase in the trap and induced the displacement of an equivalent volume of solution [45,47].

The duration of the test was 18 days for cycles I and III and 19 days for cycle II. The substrate-to-inoculum ratio was set at 0.3 , in terms of VS; and biogas collection and measurement were operated three times per week. The net specific biochemical methane production was calculated by the following equation:

$$
\mathrm{BMP}\left[\frac{\mathrm{NmL} \mathrm{CH}_{4}}{\mathrm{~g} \mathrm{VS}}\right]=\frac{\left(\mathrm{V}_{\mathrm{CH}_{4, \mathrm{~s}}}-\mathrm{V}_{\mathrm{CH}_{4, \text { blank }}}\right)\left[\mathrm{NmL} \mathrm{CH}_{4}\right]}{\mathrm{VS}_{\mathrm{s}}[\mathrm{gVS}]}
$$

where $\left(\mathrm{V}_{\mathrm{CH}_{4, s}}-\mathrm{V}_{\mathrm{CH}_{4, \text { blank }}}\right)$ is the net methane production measured at the end of the test (normal volumes) and $\mathrm{VS}_{\mathrm{s}}$ is the mass of volatile solids of the substrate added to the batch. 


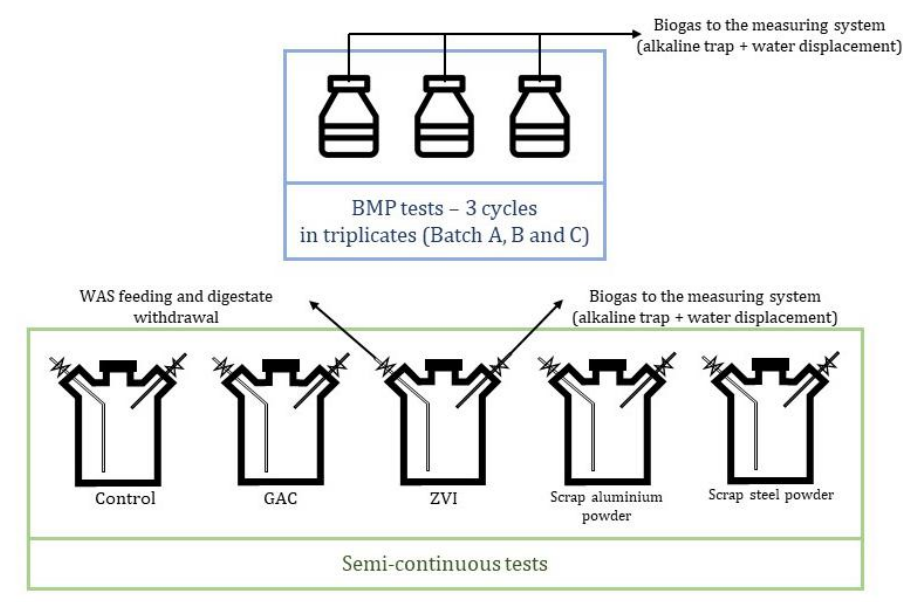

Figure 1. Experimental design scheme.

\subsection{Semi-Continuous Test Setup}

The semi-continuous test was carried out in five reactors designated with numbers from 1 to 5, indicating blank, GAC, ZVI, scrap aluminium powder, and scrap iron powder supplemented reactors, respectively.

The bottles used were the same as for the batch tests, but the two lateral necks were equipped with valves and flexible tubes, allowing for periodic biogas collection, feeding of the substrate, and withdrawal of the digestate by a graduated $100 \mathrm{~mL}$ syringe (Figure 1). In this case, the reactors were placed in the thermostatic cabinet at $35 \pm 0.5^{\circ} \mathrm{C}$ and mixed by a magnetic stirrer throughout the test period.

At the beginning of the experiment, each reactor was loaded with $650 \mathrm{~mL}$ of inoculum, $50 \mathrm{~mL}$ of thickened WAS (i.e., substrate), and (with the exception of the blank reactor) with $7 \mathrm{~g}$ of additive, as previously explained. HRT and Organic Loading Rate (OLR) were kept constant during the whole experiment and set at 14 days and $1.3 \mathrm{gvs} / \mathrm{L} \cdot \mathrm{d}$, respectively; this corresponded to a loading of $50 \mathrm{~mL} /$ day of sludge. Semi-continuous reactors were fed three times per week $(100 \mathrm{~mL}$ of sludge on Monday and Wednesday and $150 \mathrm{~mL}$ on Friday) for 58 days and then operated in batch mode until day 77. Before feeding, an equal amount of digestate was extracted. During sludge extraction, mixing speed was reduced in order to allow the deposition of the additives and thus avoid the washout of the conductive materials.

In order to investigate the process, $\mathrm{pH}$, conductivity, TS, VS, COD, VFA, total nitrogen $(\mathrm{TN})$, ammonium $\left(\mathrm{N}-\mathrm{NH}_{4}{ }^{+}\right)$, reactive phosphorus $\left({\mathrm{P}-\mathrm{PO}_{4}}^{3-}\right)$, sulfate $\left(\mathrm{SO}_{4}{ }^{2-}\right)$, and alkalinity (ALK) were evaluated on average weekly digestate samples.

The blank was fed with substrate only on days $1,4,9,14,16,18$ because absent or extremely limited biogas production was observed. The WAS feeding was interrupted to avoid overload conditions. Moreover, in order to establish an effective AD process, on day 7 , the WAS was replaced by an equal amount $(100 \mathrm{~mL}$; the substrate dose for two days) of inoculum. For analogous reasons, the feeding of the reactor supplemented with ZVI was stopped from days 21-35 and again from day 42 to the end of the experiment. The withdrawal of digestate samples from the blank and the reactor with ZVI was interrupted when the WAS feeding was stopped.

\subsection{Analytical Methods}

During the experiments, the samples were analyzed by means of standard methods [44].

Specifically, $\mathrm{pH}$ and conductivity were detected using bench analyzers. Total and volatile solids (TS and VS) were estimated by weight analysis after drying the samples at $105{ }^{\circ} \mathrm{C}$ and $550{ }^{\circ} \mathrm{C}$, respectively. COD was determined by means of digestion with $\mathrm{K}_{2} \mathrm{Cr}_{2} \mathrm{O}_{7}$ and volumetric titration with $\left(\mathrm{NH}_{4}\right)_{2} \mathrm{Fe}\left(\mathrm{SO}_{4}\right)_{2} \cdot 6 \mathrm{H}_{2} \mathrm{O}$. Volatile fatty acids (VFA) were detected by means of distillation and titration with $\mathrm{NaOH}$. Total nitrogen (TN) was estimated through digestion before sample titration with $\mathrm{NaOH}$ and $\mathrm{HCl}$. Alkalinity (ALK) 
was measured by the potentiometric procedure. Ammoniacal nitrogen $\left(\mathrm{N}_{-} \mathrm{NH}_{4}{ }^{+}\right)$, reactive phosphorus $\left(\mathrm{P}_{-} \mathrm{PO}_{4}{ }^{3-}\right)$, and sulfate $\left(\mathrm{SO}_{4}{ }^{2-}\right)$ were obtained by spectrophotometric analyses. Metals were measured through atomic absorption spectrophotometry. Each analysis was carried out in triplicate and the mean value was used.

\section{Results}

\subsection{BMP Batch Tests}

Figure 2 shows the results of the batch tests carried out on the three WAS samples used as substrates; each line shows the net methane specific production from a single batch. It is evident that, out of the nine tests, two failed (Figure 2c, batch A, B) (with production lower than that of the inoculum) and, for the other seven, two (Figure 2a, batch A; Figure 2c, batch C) had significantly lower production than the others (Figure 2a, batch B, C; Figure 2b, batch A, B, C). These findings could be due to the presence of inhibiting compounds in the sludge (e.g., hydrocarbons), demonstrating the difficulty in anaerobically digesting this specific substrate. Considering only the five higher values, the average BMP in 14 days (i.e., the sludge retention time (SRT) set in the semi-continuous tests) was $292 \mathrm{NmL}_{\mathrm{CH} 4} / \mathrm{g}_{\mathrm{VS}}$; considering all the seven tests with net positive production, it was $242 \mathrm{NmL}_{\mathrm{CH} 4} / \mathrm{g}_{\mathrm{VS}}$.

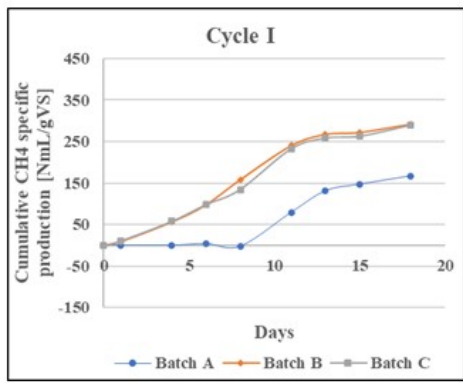

(a)

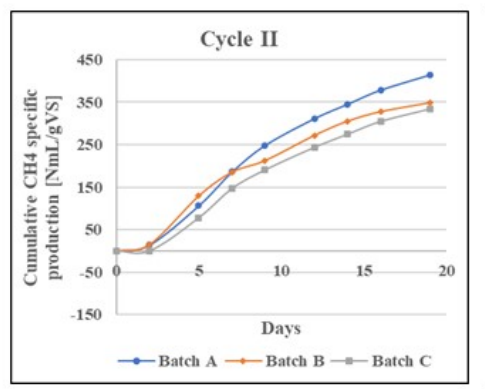

(b)

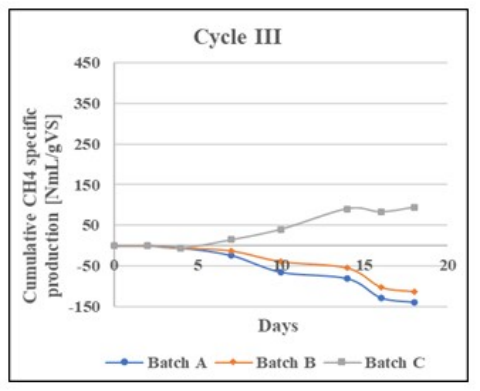

(c)

Figure 2. Specific cumulated biomethane production from three cycles of batch tests ((a) - cycle I; (b) - cycle II; (c) - cycle III). Each cycle was conducted in triplicate at $\mathrm{T}=35 \pm 0.5^{\circ} \mathrm{C}$ and with a substrate-to-inoculum ratio of 0.3 .

\subsection{Semi-Continuous Tests}

\subsubsection{Biomethane Production}

The blank reactor did not produce any biogas, even if several attempts (e.g., feeding suspension and reinoculation) were performed in order to establish a stable AD process. Cumulated specific biomethane production during the regime phase was significantly higher for GAC- and Al-supplemented reactors with respect to those amended with ZVI and steel. In the reactor containing ZVI, production was significant only for the first 14 days; then, if feeding was suspended to avoid overload, it slightly recovered only on days 35-39 and finally stopped (Figure 3a). During the post-regime phase (days 53-77) with reactors operating in batch mode, limited production was observed (Figure 3a).

The first 14 days of operation were considered the acclimation phase and the processes were unsteady (Figure 3b-e); this was clearly shown by the methane yield, which was significantly more regular for days 14-53 in the reactors supplemented with ZVI, Steel, and Al while, for GAC, it assumed a decreasing trend which tended to stabilize from day 28 (Figure 3b,c). The specific yield in the regime phase (i.e., considering only days 14-53 in the calculation) was $230 \mathrm{NmL}_{\mathrm{CH} 4} / \mathrm{g}_{\mathrm{Vs}}$ for the GAC reactor, $212 \mathrm{NmL}_{\mathrm{CH} 4} / \mathrm{g}_{\mathrm{Vs}}$ for $\mathrm{Al}$, $27 \mathrm{NmL}_{\mathrm{CH} 4} / \mathrm{g}_{\mathrm{VS}}$ for steel, and $18 \mathrm{NmL}_{\mathrm{CH} 4} / \mathrm{g}_{\mathrm{VS}}$ for $\mathrm{ZVI}$. 


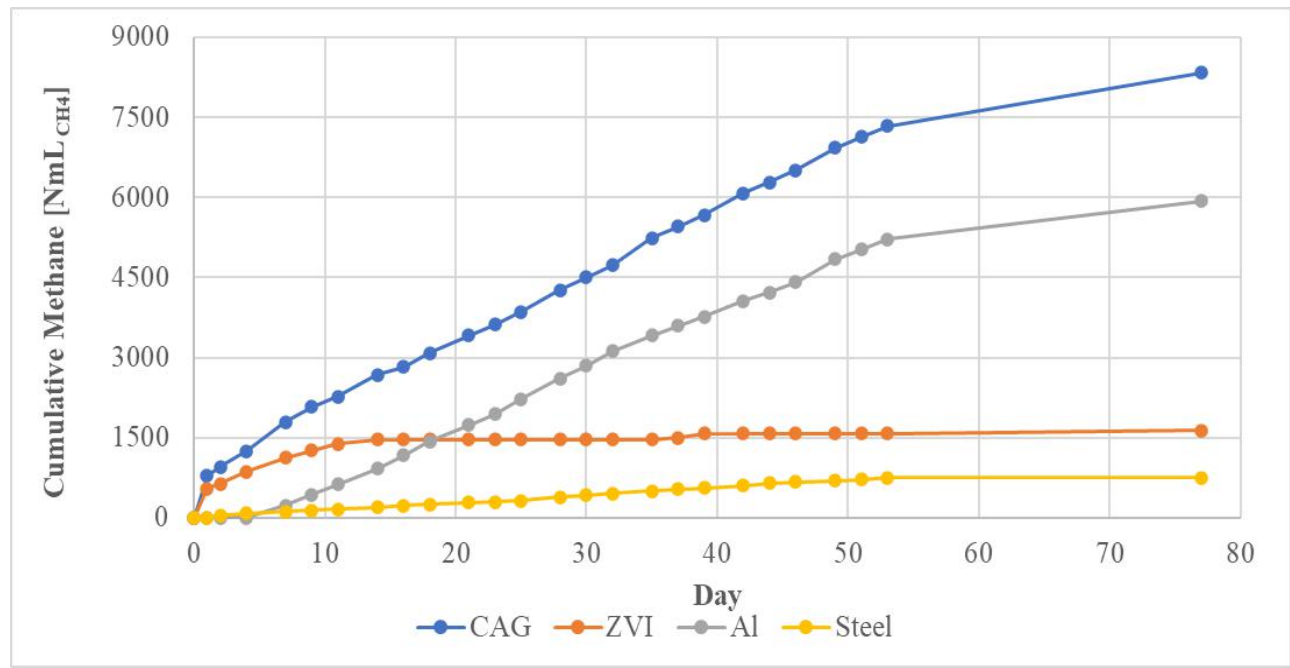

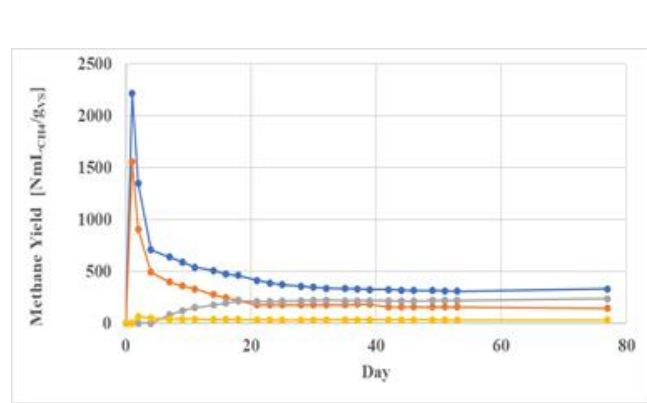

(b)

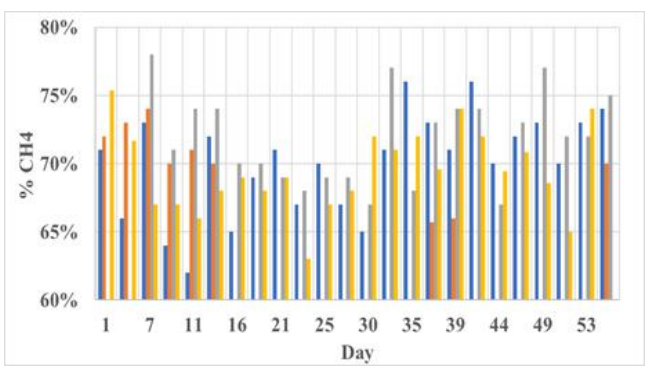

(d) (a)

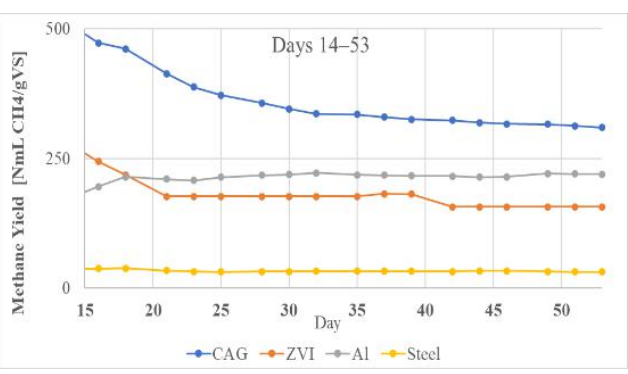

(c)

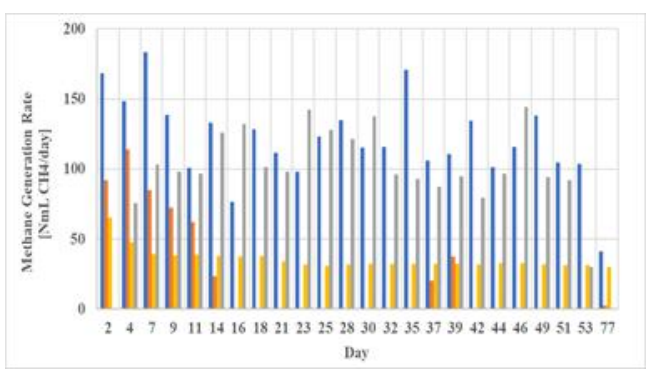

(e)

Figure 3. Cumulated specific methane production (a), specific methane yield (b), specific methane yield for the regime phase (days 14-53) (c); \%CH4 in biogas (d) and daily generation rate (e) during the semi-continuous tests. The color codes are always the same for all figures.

The methane daily generation rate showed a very peculiar trend (Figure 3e). Analysing the two more interesting reactors ( $\mathrm{GAC}$ and $\mathrm{Al}$ ), it is clear that the daily generation rate for the GAC reactor was significantly higher in the first 11 days (during the acclimation phase); after this period, that $\mathrm{Al}$ reactor showed similar performance. Regarding the methane level in the produced biogas, the percentage was between 62 and 78\% (Figure 3d), without significant differences among the reactors.

The fraction of $\mathrm{CO}_{2}$ in the produced biogas was the difference between $100 \%$ and the percentage of methane plotted in Figure 3d, as the fractions of other gases (other than $\mathrm{CH}_{4}$ and $\mathrm{CO}_{2}$ ) in biogas are negligible.

\subsubsection{Other Process Parameters}

TS decreased very quickly in all reactors, including the blank and the reactor with ZVI, until the fourth week (Figure 4a), due to the progressive dilution of inoculum with WAS and to the consumption of the biodegradable substrate. It is interesting to note 
that the reactor supplemented with GAC allowed for the highest reduction of TS, whose concentration tended to stabilize at a value close to $10 \mathrm{~g} / \mathrm{L}$. In the reactor with $\mathrm{Al}$ powder, the TS was around $15-17 \mathrm{~g} / \mathrm{L}$ from the 4 th to 8 th weeks and had declined to $10 \mathrm{~g} / \mathrm{L}$ by the end of the experiment.

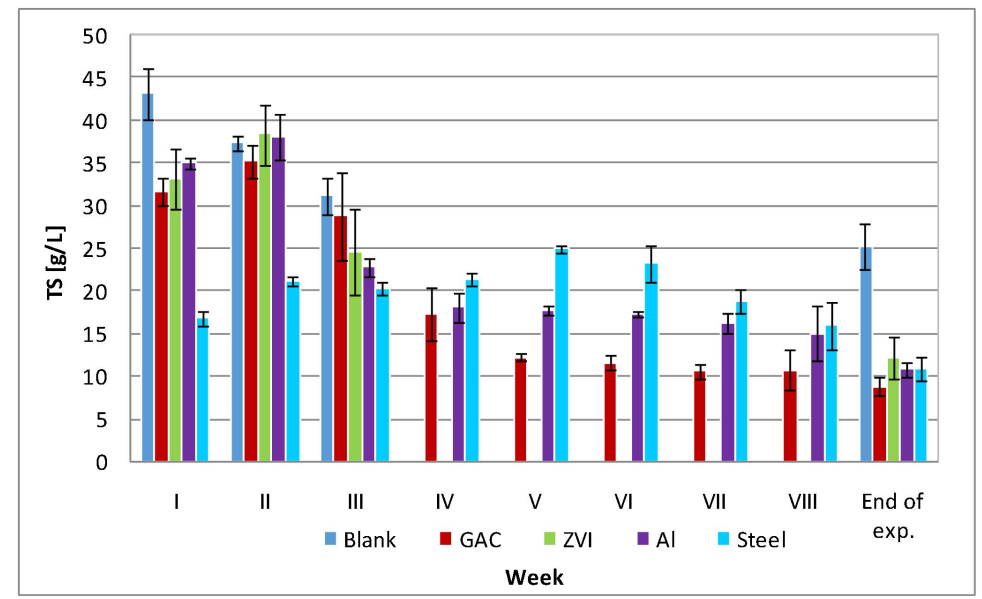

(a)

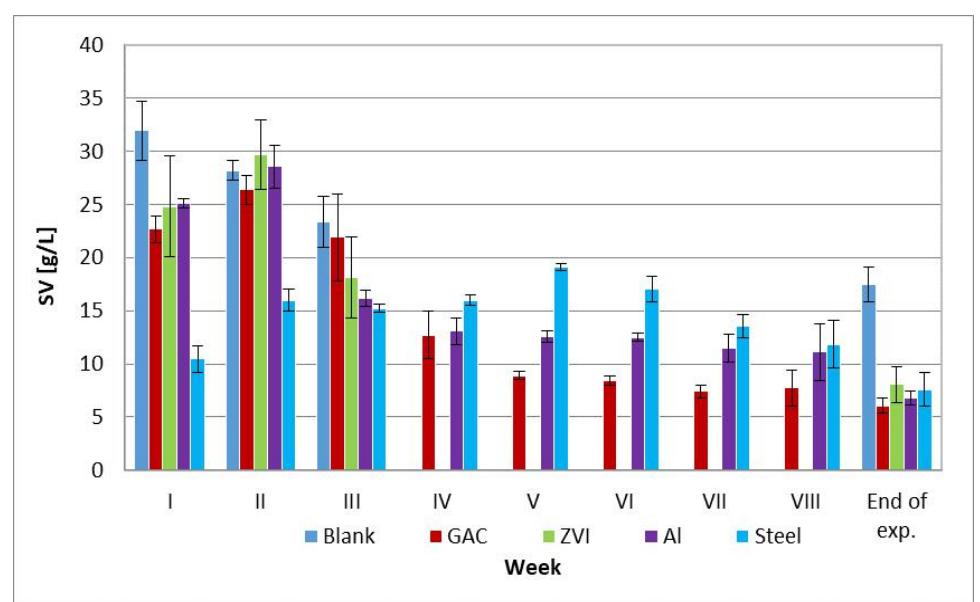

(b)

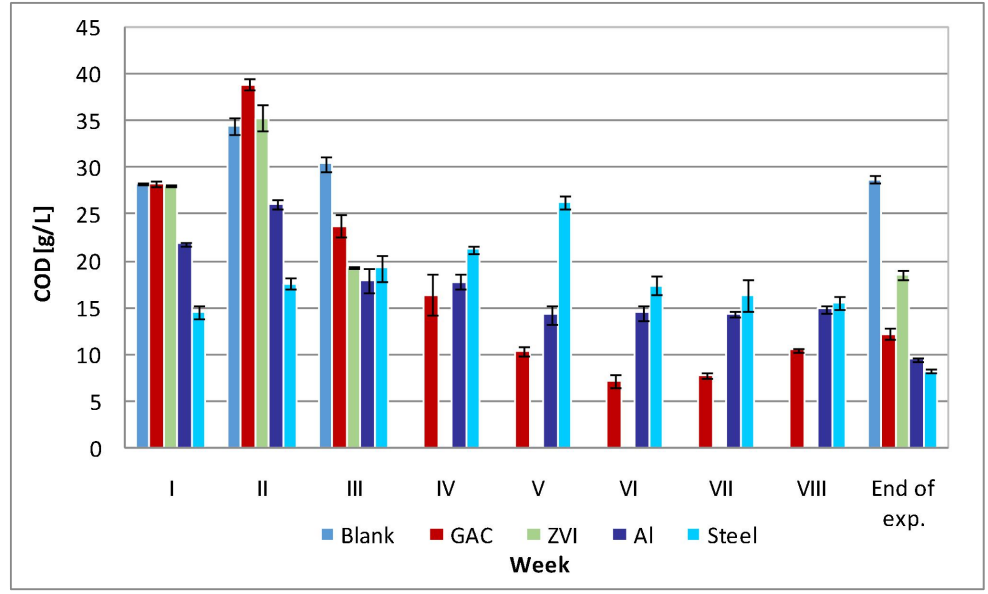

(c)

Figure 4. TS (a), VS (b), and COD (c) in semi-continuous tests (lacking data refer to periods where feeding was not performed and, therefore, digestate was not extracted). 
In the case of the reactor supplied with Steel powder, a singular behaviour was monitored. Indeed, compared to the other reactors, the TS showed a lower initial value, which grew until the 5th week and then progressively decreased, reaching a concentration comparable to those of the reactors containing GAC and Al. It is possible that, at the beginning of the test, the addition of steel powder caused the enhanced deposition of suspended solids at the bottom of the reactor. The increase of TS in the following weeks denotes that the degradation of organic matter was lower than the amount of solids fed with the WAS. Only from the 6th week did a significant degradation of solid content appear. At the end of the experiment, the high residual amount of TS in the blank reactor underlined the ineffective evolution of the digestion process in the absence of additives.

The trends of VS concentrations followed those of TS described above (Figure $4 \mathrm{~b}$ ). This parallelism confirms that the variation of solids during the experiments was mainly attributable to the degradation of the volatile fraction. With very few exceptions, VS were between 70 and $75 \%$ for all tests. The VS fractions decreased to just below $70 \%$ at the end of the experiments, when the reactors were operated in batch mode. In this period, the absence of WAS feeding clearly allowed a higher reduction of VS.

The trends of COD concentration, as expected, reflected those of volatile solids (Figure 4c). This correspondence underlines the reliability of the analyses carried out. It can be easily noticed that the COD in the GAC reactor notably reduced between the 2nd week and the 6th week, which is consistent with the observed biomethane production trend. The removal of organic matter was slower in the reactor with $\mathrm{Al}$ powder, whose COD concentration stabilized at around to $15 \mathrm{~g} / \mathrm{L}$ and further decreased only when the system was operated in batch mode.

$\mathrm{pH}$ is a main parameter affecting the stability of anaerobic processes; in a mixed culture digester, as methanogenesis is considered the limiting phase, the $\mathrm{pH}$ should be in the range 6.8-8.0 to avoid inhibition phenomena [15].

For each reactor monitored, the $\mathrm{pH}$ remained in the optimal range for $\mathrm{AD}$ with values between 7 and 8 (Figure 5). These trends suggest that the inhibition of methanogen activity related to $\mathrm{pH}$ values did not occur.

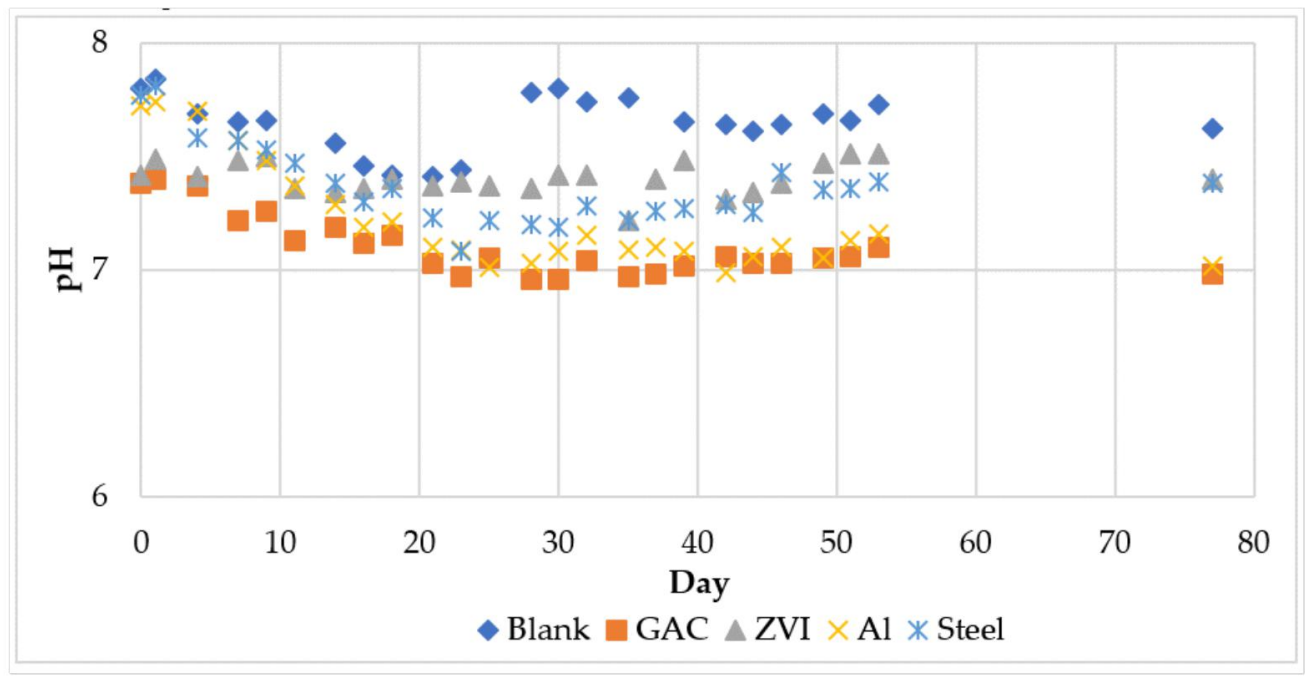

Figure 5. Measured $\mathrm{pH}$ in semi-continuous tests.

Despite the adequate $\mathrm{pH}$ values, very high VFA/ALK ratios were detected during the entire operating period for each reactor investigated (Figure 6a). Indeed, with few exceptions, the VFA/ALK ratio was always greater than $1.5 \mathrm{~g}_{\mathrm{CH} 3 \mathrm{COOH}} / \mathrm{g}_{\mathrm{CaCO}}$. Alkalinity (data not reported) show quite uniform, continuously decreasing values in all reactors, while VFA concentration is higher in metal supplemented reactors and especially in that containing Al. 


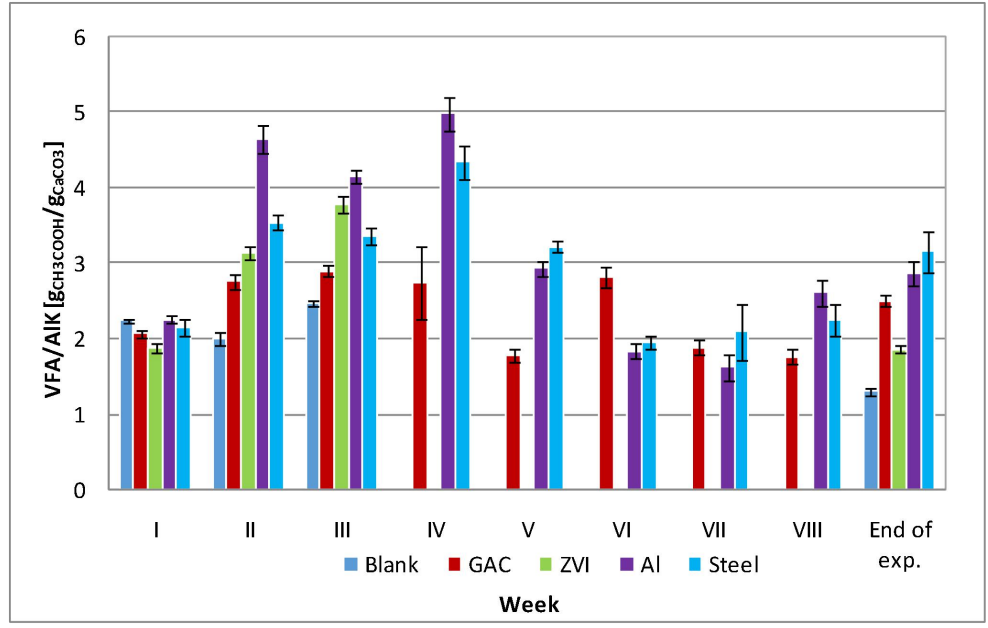

(a)

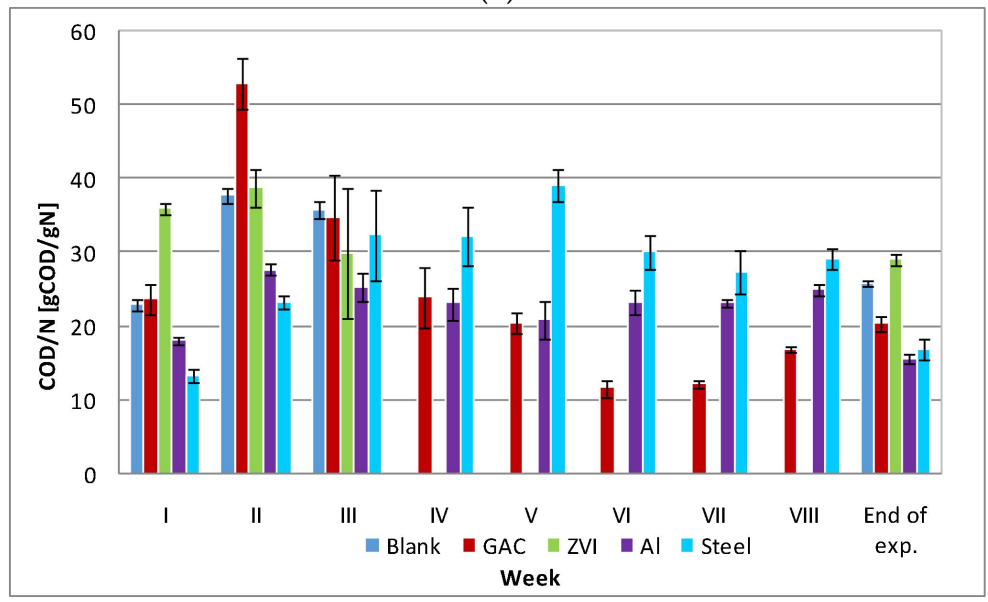

(b)

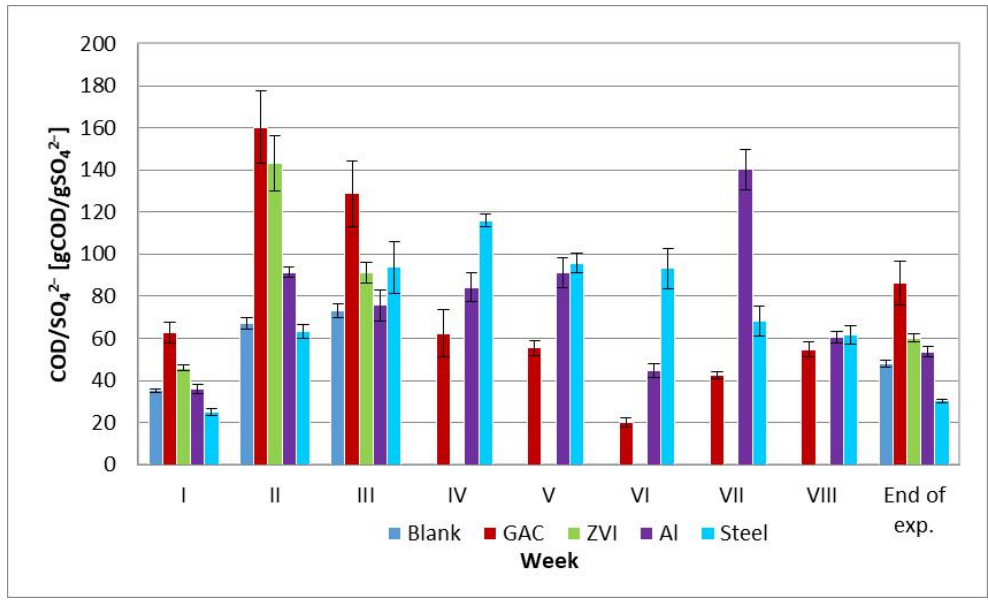

(c)

Figure 6. VFA/ $\operatorname{ALK}(\mathbf{a}), \mathrm{COD} / \mathrm{N}(\mathbf{b})$, and $\mathrm{COD} / \mathrm{SO}_{4}{ }^{2-}$ (c) ratios in semi-continuous tests (lacking data refer to periods where feeding was not performed and, therefore, digestate was not extracted).

The WAS used in this work had an adequate COD/N ratio (Table 1); during the semicontinuous tests, the COD/N ratios were always quite low for all the reactors monitored (Figure $6 \mathrm{~b}$ ). On the basis of these findings, it can be stated that the availability of nitrogen is not a limiting factor for WAS digestion. As a consequence of the transformation of most of the organic nitrogen into reduced inorganic form, the TN in the reactors consisted 
mainly of dissolved ammoniacal nitrogen, which reached maximum concentrations near to $1.2 \mathrm{~g} / \mathrm{L}$. The detected ammonium amounts were much lower than the threshold value (about $3 \mathrm{~g} / \mathrm{L}$ ), which is considered the upper tolerable limit for AD [15]. Therefore, the occurrence of potential toxic phenomena due to excessive amounts of ammoniacal nitrogen could also be excluded.

With a COD $/ \mathrm{SO}_{4}{ }^{2-}$ ratio between 4 and $10 \mathrm{~g} \mathrm{COD} / \mathrm{g}_{\mathrm{SO}}$, a partial toxic effect occurs, while a total inhibition of methanogens takes place when the ratio is less than $4 \mathrm{~g} \mathrm{COD} / \mathrm{g}_{\mathrm{SO}}$ [48]. The WAS used in this work showed extremely high $\mathrm{COD} / \mathrm{SO}_{4}{ }^{2-}$ values, indicating a notable surplus of organic matter (Table 1). During the entire operational period, the $\mathrm{COD} / \mathrm{SO}_{4}{ }^{2-}$ ratio remained far above $10 \mathrm{~g} \mathrm{COD} / \mathrm{g}_{\mathrm{SO} 4}$ in all reactors (Figure 6c). The observed trends clearly indicate that no competition or inhibition effects attributable to sulfate degradation occurred in the conducted experiments $[15,23,48]$.

\subsubsection{Characterization of the Final Digestates}

The characterization of the effluent of the semi-continuous reactors at the end of the experiments (Table 2) clearly shows, as only ZVI addition influences significantly the presence of iron in the digestate.

Table 2. Characterization of the final digestates.

\begin{tabular}{|c|c|c|c|c|c|c|c|c|}
\hline & $\begin{array}{c}\mathrm{Fe} \\
{[\mathrm{mg} / \mathrm{L}]}\end{array}$ & $\begin{array}{c}\mathrm{Al} \\
{[\mathrm{mg} / \mathrm{L}]}\end{array}$ & $\begin{array}{c}\mathrm{Mn} \\
{[\mathrm{mg} / \mathrm{L}]}\end{array}$ & $\begin{array}{c}\mathrm{Zn} \\
{[\mathrm{mg} / \mathrm{L}]}\end{array}$ & $\begin{array}{c}\mathrm{Pb} \\
{[\mathrm{mg} / \mathrm{L}]}\end{array}$ & $\begin{array}{c}\mathrm{Cu} \\
{[\mathrm{mg} / \mathrm{L}]}\end{array}$ & $\begin{array}{c}\mathrm{Cr} \\
{[\mathrm{mg} / \mathrm{L}]}\end{array}$ & $\begin{array}{c}\mathrm{Ni} \\
{[\mathrm{mg} / \mathrm{L}]}\end{array}$ \\
\hline BlankDigestate & $58.1 \pm 8.3$ & $147.9 \pm 20.6$ & $4.6 \pm 0.2$ & $6.4 \pm 0.0$ & $0.97 \pm 0.07$ & $4.26 \pm 0.22$ & - & $2.20 \pm 0.17$ \\
\hline $\begin{array}{l}\text { Blank Liquid } \\
\text { phase }\end{array}$ & $3.9 \pm 0.2$ & $11.1 \pm 0.4$ & $0.10 \pm 0.0$ & $0.4 \pm 0.0$ & $0.49 \pm 0.05$ & $0.18 \pm 0.09$ & - & $0.25 \pm 0.03$ \\
\hline $\begin{array}{c}\text { GAC } \\
\text { Digestate }\end{array}$ & $55.9 \pm 6.9$ & $135.5 \pm 7.7$ & $1.7 \pm 0.1$ & $7.2 \pm 0.1$ & $0.68 \pm 0.05$ & $2.98 \pm 0.25$ & - & $0.21 \pm 0.04$ \\
\hline $\begin{array}{c}\text { GAC } \\
\text { Liquid phase }\end{array}$ & $6.2 \pm 0.7$ & $12.3 \pm 0.5$ & $0.2 \pm 0.1$ & $0.9 \pm 0.1$ & $0.30 \pm 0.07$ & $0.39 \pm 0.02$ & - & $0.14 \pm 0.03$ \\
\hline $\begin{array}{c}\text { ZVI } \\
\text { Digestate }\end{array}$ & $140.1 \pm 19.5$ & $115.5 \pm 3.3$ & $1.8 \pm 0.1$ & $8.0 \pm 0.5$ & $0.63 \pm 0.04$ & $5.44 \pm 0.58$ & - & $0.18 \pm 0.09$ \\
\hline $\begin{array}{c}\text { ZVI } \\
\text { Liquid phase }\end{array}$ & $19.8 \pm 1.8$ & $18.9 \pm 1.1$ & $0.3 \pm 0.0$ & $1.2 \pm 0.0$ & $0.28 \pm 0.05$ & $0.58 \pm 0.02$ & - & $0.04 \pm 0.00$ \\
\hline $\begin{array}{c}\mathrm{Al} \\
\text { Digestate }\end{array}$ & $43.7 \pm 0.6$ & $189.5 \pm 4.5$ & $0.7 \pm 0.1$ & $7.9 \pm 0.2$ & $1.10 \pm 0.09$ & $3.65 \pm 0.33$ & - & $1.02 \pm 0.06$ \\
\hline $\begin{array}{c}\mathrm{Al} \\
\text { Liquid phase }\end{array}$ & $16.6 \pm 4.2$ & $67.4 \pm 0.5$ & $0.3 \pm 0.0$ & $3.1 \pm 0.1$ & $0.92 \pm 0.04$ & $1.36 \pm 0.12$ & - & $0.31 \pm 0.01$ \\
\hline $\begin{array}{c}\text { Steel } \\
\text { Digestate }\end{array}$ & $62.5 \pm 4.5$ & $103.2 \pm 5.9$ & $1.1 \pm 0.2$ & $6.9 \pm 0.1$ & $1.41 \pm 0.04$ & $2.07 \pm 0.26$ & - & $0.91 \pm 0.07$ \\
\hline $\begin{array}{c}\text { Steel } \\
\text { Liquid phase }\end{array}$ & $27.4 \pm 3.5$ & $45.0 \pm 2.7$ & $0.4 \pm 0.1$ & $2.6 \pm 0.1$ & $0.57 \pm 0.06$ & $0.95 \pm 0.06$ & - & $0.42 \pm 0.07$ \\
\hline
\end{tabular}

The relatively high concentrations of iron and aluminum detected also in the blank and in the GAC supplemented reactors (Table 2) are due to the use of coagulant agents (which are used to promote sludge sedimentation) in the wastewater treatment plant from which the substrates were taken.

\section{Discussion}

\subsection{BMP Batch Tests}

BMP test results demonstrate the difficulty in anaerobically digesting this specific substrate. This could be due to several causes; the most probable is the very high VFA/ALK of the substrate and the eventual presence of inhibiting substances. The reduced alkalinity is probably linked to an unbalanced process in the water line of the WWTP; in fact, nitrification, that is an alkalinity consuming process, is well established in the plant while pre-denitrification is very inefficient due to a limited recirculation of the nitrate-rich sludge. The BMP at 14 days of AD was on the order of $240-290 \mathrm{NmL}_{\mathrm{CH} 4} / \mathrm{g}_{\mathrm{Vs}}$. These values, by 
considering the average COD/VS ratio (1.33) of the sludge fed in the bottles, became about $180-220 \mathrm{NmL}_{\mathrm{CH} 4} / \mathrm{g}_{\mathrm{COD}}$.

\subsection{Semi-Continuous Tests}

The lack of production in the blank reactor fully confirmed that this specific WAS was very difficult to digest. This difficulty was, most probably, attributable to the unbalanced VFA/ALK ratios due to the characteristics of the sludge fed to the reactors, which was characterized by very low levels of alkalinity, as compared to the VFA content (Table 1).

The initial high methane production observed in the reactor fed with GAC suggests that the addition of this material immediately creates favourable conditions in the mixture, allowing for the methanisation of VFA. The positive effect, however, reduced with time, means that it is possible that, in spite of the precautions taken, GAC is removed with digestate during feeding.

On the contrary, the methane production phase in the Al reactor started with a delay of about two weeks. This denotes that the digestion process requires a superior period to allow the adaptation to the conditions created by the presence of Al. Nevertheless, once the startup phase was completed, the reactor with $\mathrm{Al}$ powder guaranteed a stable daily production of about $220 \mathrm{NmL}_{\mathrm{CH} 4}$ / day; comparable to that monitored in the GAC reactor. If the first 14 days (acclimation phase) are not considered, the biomethane production of the GAC reactor was only $12 \%$ higher than that of the $\mathrm{Al}$ one. It was also noticeable that the regime specific methane yield was 13-36\% higher than BMP for the GAC reactor while, for the Al reactor, actual yield in the semi-continuous test was $10-25 \%$ lower than that of BMP. In the literature, it has been indicated that using the same substrate in continuous tests generally gives methane yields lower than those found here [49-53]. Indeed, a methane yield of $210 \mathrm{NmL}_{\mathrm{CH} 4} / \mathrm{g}_{\mathrm{VS}}$ was found using powdered activated carbon as conductive material in dry anaerobic digestion of sewage sludge [35]. A cumulative methane production of $132.1 \mathrm{~mL}_{\mathrm{CH} 4} / \mathrm{g}_{\mathrm{Vs}}$ was reached with the simultaneous addition of iron and activated carbon [53]. Therefore, the results obtained in the present study (especially those for GAC supplementation) are very significant. The values recorded for VFA/ALK were far beyond the ratios considered suitable for an effective digestion process [15,23]. Such high VFA/ALK levels clearly represent a very adverse factor for biogas production, as the activity of methanogenic bacteria can be inhibited when the VFA amount is not adequately balanced by alkaline compounds. It seems, however, that, confirming literature [38,40,42], metals addition enhance hydrolysis and this also implies that, in this case, also due to the noticeable amount of VFA present in the WAS used as substrate, the hydrolysis step is not the limiting factor for methane production.

The reactors amended with steel and ZVI did not give good results. It seems that these two supplements did not manage to boost methane production or help the bacterial consortium to develop as it is observed in the reactor containing Al. This was unexpected, especially for ZVI, as very promising results have been obtained in other cases [54]. In the reactor filled with steel powder, an appreciable conversion of organic matter started from the 5th week. The high residual levels of COD detected in the blank reactor and in the reactor fed with ZVI powder revealed the poor conversion of organic matter into biogas, in agreement with the results previously reported on $\mathrm{CH}_{4}$ production.

Also, if the toxicity due to the excessive presence of VFA certainly played a major role, it is possible that the positive effects of ZVI were limited to the unfavourable corrosion conditions linked to the slightly alkaline $\mathrm{pH}$ while, in the mentioned research, it was between 5.5 and 7. Another possible cause of the poor efficiency monitored in the ZVI reactor may be the formation of a passive layer of less-reactive products, such as maghemite $\gamma-\mathrm{Fe}_{2} \mathrm{O}_{3}$ or lepidocrocite $\gamma-\mathrm{FeOOH}[55,56]$, on the surface of the ZVI particles. In effect, while electrons can migrate almost freely through magnetite $\mathrm{Fe}_{3} \mathrm{O}_{4}$, few electrons can penetrate a maghemite or lepidocrocite layer [55]. Therefore, the presence of these corrosion products would make the ZVI particles ineffective in improving WAS digestion. 
Based on the production data monitored in this study, it seems that the use of GAC and $\mathrm{Al}$ could neutralize the adverse effects of the WAS characteristics. The results for the methane generation rate and the VFA clearly indicate how, in the Al supplemented reactor, microbial consortium adaptation was an issue at least for the first two weeks [57]; while, for GAC, the response of the system was immediate. This faster effectivity is probably attributable to the fact that, in addition to DIET promotion (which requires the selection and growth of adapted bacterial strains), GAC can absorb inhibiting compounds such as VFA [58-60]. The decreasing trend for the yield in the GAC reactor may be attributable to a progressive loss of adsorption capacity of the material which, however, preserved the electron conductivity and continued to sustain the DIET. This fact suggests that AD with GAC can benefit from continuous supplementation of carbon with the substrate.

It is clear, however, that both GAC and $\mathrm{Al}$ allowed stable and productive $\mathrm{AD}$ which would be impossible without supplements (blank) or irregular and only slightly productive with other additives (ZVI and steel).

\section{Conclusions}

In the present paper, an experimental investigation was conducted to evaluate the ability of conductive materials in enhancing WAS digestion. In this regard, GAC, granular $\mathrm{ZVI}$, and aluminium and steel scrap powders were tested in semi-continuous lab-scale digesters. The digestion of this activated sludge is hindered by the very unbalanced VFA/ALK ratio, as witnessed by the fact that in the control reactor a stable AD process was not established. The use of ZVI and steel powder did not sustain adequately methane production. This negative performance could be also attributable to the slightly alkaline $\mathrm{pH}$ in the reactors, which is able to limit the corrosion of the materials or lead to the formation of a passive layer of less-conductive corrosion products on the material surface.

Differing from the results observed for ZVI and steel powder, reactors fed with GAC and $\mathrm{Al}$ permitted the satisfactory conversion of VFA to methane. In particular, production started immediately when using GAC as an additive, while a delay of about two weeks occurred in the $\mathrm{Al}$ reactor due most probably to biomass acclimation. The stationary methane rate was about $212 \mathrm{NmL}_{\mathrm{CH} 4}$ / day for the $\mathrm{Al}$ reactor, and around $230 \mathrm{NmL}_{\mathrm{CH} 4}$ / day for the digester supplied with GAC. It is very likely that the positive effect exerted by these conductive materials was linked to DIET.

These results support the use of aluminium and GAC as conductive materials to improve the digestion of activated sludge. However, further studies need to be carried out, in order to verify the efficiency of these materials, by changing the operating conditions and specifically the dosage and the feeding mode of the conductive material.

Author Contributions: Conceptualization, P.S.C. and A.S.; methodology, P.S.C. and A.S.; investigation, P.S.C., A.S., F.F. and C.L.; writing-review and editing, P.S.C., A.S., F.F. and C.L.; visualization, P.S.C., A.S., F.F. and C.L.; supervision, P.S.C. and A.S. All authors have read and agreed to the published version of the manuscript.

Funding: This research received no external funding.

Institutional Review Board Statement: Not applicable.

Informed Consent Statement: Not applicable.

Data Availability Statement: The data presented in this study are available on request from the corresponding author. The data are not publicly available due to internal policies.

Conflicts of Interest: The authors declare no conflict of interest.

\section{References}

1. Ardern, E.; Lockett, W.T. Experiments on the oxidation of sewage without the aid of filters. J. Soc. Chem. Ind. 1914, 33, 523-539. [CrossRef]

2. Pariente, M.I.; Segura, Y.; Molina, R.; Martínez, F. Wastewater treatment as a process and a resource. Wastewater Treat. Residues Resour. Biorefinery Prod. Biofuels 2020, 19-45. [CrossRef] 
3. Tchobanoglous, G.; Burton, F.L.; Stensel, H.D. Wastewater Engineering. Treatment and Reuse; McGraw-Hill: New York, NY, USA, 2002.

4. Schmidt, J.E.; Christensen, N.; Batstone, D.J.; Trably, E.; Lyberatos, G.; Stamatelatou, K.; Kornaros, M.; Metzger, L.; Amellal, N.; Watson, J.; et al. Safe recycling of sewage sludge on agricultural land-Biowaste. Process. Saf. Environ. Prot. 2006, 84, $253-257$. [CrossRef]

5. Elalami, D.; Carrere, H.; Monlau, F.; Abdelouahdi, K.; Oukarroum, A.; Barakat, A. Pretreatment and co-digestion of wastewater sludge for biogas production: Recent research advances and trends. Renew. Sustain. Energy Rev. 2019, 114, R713-R715. [CrossRef]

6. Mannina, G.; Ekama, G.; Caniani, D.; Cosenza, A.; Esposito, G.; Gori, R.; Garrido-Baserba, M.; Rosso, D.; Olsson, G. Greenhouse gases from wastewater treatment-A review of modelling tools. Sci. Total. Environ. 2016, 551-552, 254-270. [CrossRef] [PubMed]

7. Calabrò, P.S.; Gori, M.; Lubello, C. European trends in greenhouse gases emissions from integrated solid waste management. Environ. Technol. 2015, 36, 2125-2137. [CrossRef] [PubMed]

8. Gavala, H.N.; Yenal, U.; Skiadas, I.V.; Westermann, P.; Ahring, B.K. Mesophilic and thermophilic anaerobic digestion of primary and secondary sludge. Effect of pre-treatment at elevated temperature. Water Res. 2003, 37, 4561-4572. [CrossRef]

9. Odnell, A.; Recktenwald, M.; Stensén, K.; Jonsson, B.-H.; Karlsson, M. Activity, life time and effect of hydrolytic enzymes for enhanced biogas production from sludge anaerobic digestion. Water Res. 2016, 103, 462-471. [CrossRef]

10. Speece, R.E. Anaerobic biotechnology for industrial wastewater treatment. Environ. Sci. Technol. 1983, 17, 416A-427A. [CrossRef]

11. Appels, L.; Baeyens, J.; Degrève, J.; Dewil, R. Principles and potential of the anaerobic digestion of waste-activated sludge. Prog. Energy Combust. Sci. 2008, 34, 755-781. [CrossRef]

12. Cavinato, C.; Bolzonella, D.; Valentino, F.; Fatone, F.; Cecchi, F. Mesophilic and thermophilic anaerobic co-digestion of waste activated sludge and source sorted biowaste in pilot- and full-scale reactors. Renew. Energy 2013, 55, 260-265. [CrossRef]

13. Bolzonella, D.; Pavan, P.; Battistoni, P.; Cecchi, F. Mesophilic anaerobic digestion of waste activated sludge: Influence of the solid retention time in the wastewater treatment process. Process. Biochem. 2005, 40, 1453-1460. [CrossRef]

14. Zhang, Q.; Hu, J.; Lee, D.J.; Chang, Y.; Lee, Y.-J. Sludge treatment: Current research trends. Bioresour. Technol. 2017, $243,1159-1172$. [CrossRef] [PubMed]

15. Khanal, S.K. Anaerobic Biotechnology for Bioenergy Production: Principles and Applications; Wiley: Hoboken, NJ, USA, 2009; ISBN 0813823463.

16. Abelleira-Pereira, J.M.; Pérez-Elvira, S.; Sánchez-Oneto, J.; de la Cruz, R.; Portela, J.R.; Nebot, E. Enhancement of methane production in mesophilic anaerobic digestion of secondary sewage sludge by advanced thermal hydrolysis pretreatment. Water Res. 2015, 71, 330-340. [CrossRef] [PubMed]

17. Parkin, G.F.; Owen, W.F. Fundamentals of anaerobic digestion of wastewater sludges. J. Environ. Eng. 1986, 112, 867-920. [CrossRef]

18. Carrere, H.; Dumas, C.; Battimelli, A.; Batstone, D.; Delgenes, J.-P.; Steyer, J.-P.; Ferrer, I. Pretreatment methods to improve sludge anaerobic degradability: A review. J. Hazard Mater. 2010, 183, 1-15. [CrossRef]

19. Siciliano, A.; Stillitano, M.A.; Limonti, C. Energetic valorization of wet olive mill wastes through a suitable integrated treatment: $\mathrm{H}_{2} \mathrm{O}_{2}$ with lime and anaerobic digestion. Sustainability 2016, 8, 1150. [CrossRef]

20. Ruffino, B.; Campo, G.; Genon, G.; Lorenzi, E.; Novarino, D.; Scibilia, G.; Zanetti, M. Improvement of anaerobic digestion of sewage sludge in a wastewater treatment plant by means of mechanical and thermal pre-treatments: Performance, energy and economical assessment. Bioresour. Technol. 2015, 175, 298-308. [CrossRef]

21. Carrere, H.; Antonopoulou, G.; Affes, R.; Passos, F.; Battimelli, A.; Lyberatos, G.; Ferrer, I. Review of feedstock pretreatment strategies for improved anaerobic digestion: From lab-scale research to full-scale application. Bioresour. Technol. 2016, 199, 386-397. [CrossRef]

22. Xu, Y.; Lu, Y.; Zheng, L.; Wang, Z.; Dai, X. Perspective on enhancing the anaerobic digestion of waste activated sludge. J. Hazard Mater. 2020, 389, 121847. [CrossRef]

23. Siciliano, A.; Limonti, C.; Mehariya, S.; Molino, A.; Calabro, V. Biofuel production and phosphorus recovery through an integrated treatment of agro-industrial waste. Sustainability 2018, 11, 52. [CrossRef]

24. Siciliano, A.; Limonti, C.; Curcio, G.M.; Calabrò, V. Biogas generation through anaerobic digestion of compost leachate in semi-continuous completely stirred thank reactor. Processes 2019, 7, 635. [CrossRef]

25. Wu, Y.; Wang, S.; Liang, D.; Li, N. Conductive materials in anaerobic digestion: From mechanism to application. Bioresour. Technol. 2020, 298, 122403. [CrossRef] [PubMed]

26. Dubé, C.-D.; Guiot, S.R. Direct interspecies electron transfer in anaerobic digestion: A Review. Adv. Biochem. Eng. Biotechnol. 2015, 151, 101-115. [CrossRef]

27. Baek, G.; Kim, J.; Kim, J.; Lee, C. Role and potential of direct interspecies electron transfer in anaerobic digestion. Energies 2018, 11, 107. [CrossRef]

28. Gu, M.; Yin, Q.; Liu, Y.; Du, J.; Wu, G. New insights into the effect of direct interspecies electron transfer on syntrophic methanogenesis through thermodynamic analysis. Bioresour. Technol. Rep. 2019, 7, 100225. [CrossRef]

29. Kato, S.; Hashimoto, K.; Watanabe, K. Microbial interspecies electron transfer via electric currents through conductive minerals. Proc. Natl. Acad. Sci. USA 2012, 109, 10042-10046. [CrossRef]

30. Rotaru, A.-E.; Shrestha, P.M.; Liu, F.; Markovaite, B.; Chen, S.; Nevin, K.P.; Lovley, D.R. Direct interspecies electron transfer between geobacter metallireducens and methanosarcina barkeri. Appl. Environ. Microbiol. 2014, 80, 4599-4605. [CrossRef] 
31. Lovley, D.R. Syntrophy Goes electric: Direct interspecies electron transfer. Annu. Rev. Microbiol. 2017, 71, 643-664. [CrossRef]

32. Barua, S.; Dhar, B.R. Advances towards understanding and engineering direct interspecies electron transfer in anaerobic digestion. Bioresour. Technol. 2017, 244, 698-707. [CrossRef]

33. Calabrò, P.S.; Fazzino, F.; Folino, A.; Paone, E.; Komilis, D. Semi-continuous anaerobic digestion of orange peel waste: Effect of activated carbon addition and alkaline pretreatment on the process. Sustainability 2019, 11, 3386. [CrossRef]

34. Yang, Y.; Zhang, Y.; Li, Z.; Zhao, Z.; Quan, X.; Zhao, Z. Adding granular activated carbon into anaerobic sludge digestion to promote methane production and sludge decomposition. J. Clean. Prod. 2017, 149, 1101-1108. [CrossRef]

35. Pan, C.; Fu, X.; Lu, W.; Ye, R.; Guo, H.; Wang, H.; Chusov, A. Effects of conductive carbon materials on dry anaerobic digestion of sewage sludge: Process and mechanism. J. Hazard Mater. 2020, 384, 121339. [CrossRef] [PubMed]

36. Yan, W.; Zhang, L.; Wijaya, S.M.; Zhou, Y. Unveiling the role of activated carbon on hydrolysis process in anaerobic di-gestion. Bioresour. Technol. 2020, 296, 122366. [CrossRef] [PubMed]

37. Wei, J.; Hao, X.; van Loosdrecht, M.C.; Li, J. Feasibility analysis of anaerobic digestion of excess sludge enhanced by iron: A review. Renew. Sustain. Energy Rev. 2018, 89, 16-26. [CrossRef]

38. Feng, Y.; Zhang, Y.; Quan, X.; Chen, S. Enhanced anaerobic digestion of waste activated sludge digestion by the addition of zero valent iron. Water Res. 2014, 52, 242-250. [CrossRef] [PubMed]

39. Lizama, A.C.; Figueiras, C.C.; Pedreguera, A.Z.; Ruiz Espinoza, J.E. Enhancing the performance and stability of the an-aerobic digestion of sewage sludge by zero valent iron nanoparticles dosage. Bioresour. Technol. 2019, 275, 352-359. [CrossRef]

40. Zhen, G.; Lu, X.; Liu, Y.Y.; Zhao, Y. Influence of zero valent scrap iron (ZVSI) supply on methane production from waste activated sludge. Chem. Eng. J. 2015, 263, 461-470. [CrossRef]

41. Zhang, Y.; Feng, Y.; Yu, Q.; Xu, Z.; Quan, X. Enhanced high-solids anaerobic digestion of waste activated sludge by the addition of scrap iron. Bioresour. Technol. 2014, 159, 297-304. [CrossRef]

42. Peng, H.; Zhang, Y.; Tan, D.; Zhao, Z.; Zhao, H.; Quan, X. Roles of magnetite and granular activated carbon in improvement of anaerobic sludge digestion. Bioresour. Technol. 2018, 249, 666-672. [CrossRef]

43. Collivignarelli, M.C.; Abbà, A.; Frattarola, A.; Miino, M.C.; Padovani, S.; Katsoyiannis, I.; Torretta, V. Legislation for the reuse of biosolids on agricultural land in europe: Overview. Sustainability 2019, 11, 6015. [CrossRef]

44. American Public Health Association; American Water Works Association; Water Environment Association. Standard Methods for the Examination of Water and Wastewater, 22nd ed.; Rice, E.W., Baird, R.B., Eaton, A.E., Clesceri, L.S., Eds.; American Public Health Association, American Water Works Association, Water Environment Federation: Washington, DC, USA, 2012; ISBN 9780875530130.

45. Calabrò, P.S.; Paone, E.; Komilis, D. Strategies for the sustainable management of orange peel waste through anaerobic digestion. J. Environ. Manag. 2018, 212, 462-468. [CrossRef] [PubMed]

46. Calabrò, P.S.; Panzera, M. Biomethane production tests on ensiled orange peel waste. Int. J. Heat Technol. 2017, 35, S130-S136. [CrossRef]

47. Schievano, A.; Pognani, M.; D’Imporzano, G.; Adani, F. Predicting anaerobic biogasification potential of ingestates and digestates of a full-scale biogas plant using chemical and biological parameters. Bioresour. Technol. 2008, 99, 8112-8117. [CrossRef] [PubMed]

48. Yilmaz, T.; Erdirencelebi, D.; Berktay, A. Effect of COD/SO ratio on anaerobic treatment of landfill leachate during the start-up period. Environ. Technol. 2011, 33, 313-320. [CrossRef] [PubMed]

49. Zhang, C.; Su, H.; Tan, T. Batch and semi-continuous anaerobic digestion of food waste in a dual solid-liquid system. Bioresour. Technol. 2013, 145, 10-16. [CrossRef]

50. Ruffino, B.; Fiore, S.; Roati, C.; Campo, G.; Novarino, D.; Zanetti, M. Scale effect of anaerobic digestion tests in fed-batch and semi-continuous mode for the technical and economic feasibility of a full scale digester. Bioresour. Technol. 2015, 182, 302-313. [CrossRef] [PubMed]

51. Browne, J.D.; Allen, E.; Murphy, J.D. Assessing the variability in biomethane production from the organic fraction of municipal solid waste in batch and continuous operation. Appl. Energy 2014, 128, 307-314. [CrossRef]

52. Moeller, L.; Zehnsdorf, A.; Müller, R.A. Effect of triticale milling coarseness on biogas production. Chem. Ing. Tech. 2018, 90, 249-255. [CrossRef]

53. Wang, T.; Qin, Y.; Cao, Y.; Han, B.; Ren, J. Simultaneous addition of zero-valent iron and activated carbon on enhanced mesophilic anaerobic digestion of waste-activated sludge. Environ. Sci. Pollut. Res. 2017, 24, 22371-22381. [CrossRef]

54. Calabrò, P.S.; Fazzino, F.; Folino, A.; Scibetta, S.; Sidari, R. Improvement of semi-continuous anaerobic digestion of pre-treated orange peel waste by the combined use of zero valent iron and granular activated carbon. Biomass Bioenergy 2019, $129,105337$. [CrossRef]

55. Huang, Y.H.; Zhang, T.C. Effects of dissolved oxygen on formation of corrosion products and concomitant oxygen and nitrate reduction in zero-valent iron systems with or without aqueous $\mathrm{Fe}^{2+}$. Water Res. 2005, 39, 1751-1760. [CrossRef] [PubMed]

56. Siciliano, A. Removal of $\mathrm{Cr}(\mathrm{VI})$ from water using a new reactive material: Magnesium oxide supported nanoscale Zero-Valent iron. Materials 2016, 9, 666. [CrossRef] [PubMed]

57. Calabrò, P.S.; Fòlino, A.; Tamburino, V.; Zappia, G.; Zema, D.A. Increasing the tolerance to polyphenols of the anaerobic digestion of olive wastewater through microbial adaptation. Biosyst. Eng. 2018, 172, 19-28. [CrossRef]

58. Talebi, A.; Razali, Y.S.; Ismail, N.; Rafatullah, M.; Tajarudin, H. Selective adsorption and recovery of volatile fatty acids from fermented landfill leachate by activated carbon process. Sci. Total. Environ. 2020, 707, 134533. [CrossRef] [PubMed] 
59. Freitas, A.F.; Mendes, M.F.A.; Coelho, G.L.V. Thermodynamic study of fatty acids adsorption on different adsorbents. J. Chem. Thermodyn. 2007, 39, 1027-1037. [CrossRef]

60. López-Velandia, C.; Moreno-Barbosa, J.J.; Sierra-Ramirez, R.; Giraldo, L.; Moreno-Piraján, J.C. Adsorption of volatile carboxylic acids on activated carbon synthesized from watermelon shells. Adsorpt. Sci. Technol. 2014, 32, 227-242. [CrossRef] 